\title{
Collagenase Activity in Follicle During Ovulatory Process of Japanese Quail
}

\author{
Fugaku Aoki*, Makoto Mori**, Kaoru Kонмото and Yoichi ShodA \\ Department of Animal Breeding, Faculty of Agriculture, University of Tokyo, \\ Bunkyo-ku, Tokyo 113, Japan
}

\section{Introduction}

The rupture of follicles at ovulation occurs at the apical region in the mammalian follicle and in the stigma region in the avian follicle. Electron microscopic observations on rabbit follicles showed apparent dissociation of dense collagen fibers into scattered patches and a decrease of fibril in the apical region within a few minutes prior to rupture ${ }^{1)}$. BJERS ING and $\mathrm{CAJANDER}^{2)}$ also observed that collagen fibers are not only dissociated but also fragmented and that fibrils are disintegrated at ovulation. ESPEY and LIPNER ${ }^{3)}$ showed that an injection of bacterial collagenase into the cavity of preovulatory follicles of rabbit causes ovulation, which is morphologically similar to normal ovulation. In addition, an injection of a potent inhibitor for collagenase blocks normal ovulation in hamster follicles"). These data strongly suggest that proteolysis by collagenase is indispensable for the rupture of follicle at ovulation. However, the direct evidence on the involvement of collagenase for ovulation is not yet available, because the apical region in the mammalian follicles are too small for biochemical studies.

In the present study, in order to investigate the involvement of collagenase in ovulation, collagenase activities were measured in the stigma and non-stigma regions of follicles at various stages of ovulatory process in Japanese quail, in which the stigma region can be easily separated from other portions and the stage of folliclular maturation are predicted from the time of oviposition ${ }^{5)}$.

\section{Materials and Methods}

\section{Tissue Sources}

Laying Japanese quail (Coturnix coturnix japonica), 10 to 18 weeks of age, were used in the experiments. The birds were caged individually with free access to food and water. The lighting schedule was $14 \mathrm{~L}: 10 \mathrm{D}$ with lights on at 0500 . The time of oviposition of all birds was recorded daily at $0.5 \mathrm{hr}$ intervals. Time of ovulation was predicted from the time of oviposition of the previously ovulated follicle which usually occurred 15 to 30 min prior to the next ovulation ${ }^{5}$.

\footnotetext{
Received March 4, 1985

* Present address: St. Marianna University, School of Medicine, Sugao, Miyamae-ku, Kawasaki 213, Japan

** Present address: Department of Animal Science, Faculty of Agriculture, Shizuoka University, 836 Ohya, Shizuoka 422, Japan
} 
The birds were killed with a guillotine and follicles were removed at various times before and after the predicted time of ovulation. When quail were killed just before the predicted time of ovulation, the largest follicle had already ruptured in some cases. The follicles were therefore classified into those obtained just before ovulation and those obtained just after ovulation. The theca and granulosa layers were separated from the yolk in an ice-cold physiological saline by the method of GILBERT et al. $\left.{ }^{6}\right)$ In some experiments, the tissues were divided into stigma and non-stigma regions with fine scissors under the operation microscope. The tissues were stored at $-80^{\circ} \mathrm{C}$ until use.

\section{Assay of Collagenase Activity}

Collagenase activity was measured by the method of RYAN and WoESSNER ${ }^{7)}$ with slight modifications. The defrosted tissues were weighed, minced and homogenized in 17 volumes of an ice-cold assay buffer which consisted of $40 \mathrm{mM}$ Tris- $\mathrm{HCl}\left(\mathrm{pH} 7.4\right.$ at $40^{\circ} \mathrm{C}$ ), $0.15 \mathrm{M}$ $\mathrm{NaCl}$, penicillin $(112.5 \mathrm{units} / \mathrm{ml})$ and streptomycin $(250 \mu \mathrm{g} / \mathrm{ml})$. The homogenates were centrifuged at $6,000 \times \mathrm{g}$ for $20 \mathrm{~min}$ at $4^{\circ} \mathrm{C}$. The precipitate was resuspended in the original volume of the assay buffer. The collagenase assay was carried out in a total volume of 240 $\mu l$, in which $160 \mu l$ of the suspension of the precipitate was mixed with $80 \mu l$ of $30 \mathrm{mM} \mathrm{CaCl}_{2}$ to achieve a final concentration of $10 \mathrm{mM} \mathrm{CaCl}_{2}$. Incubation was performed at $40^{\circ} \mathrm{C}$ in a Dubnoff-type incubator with constant shaking. Blanks were run with $10 \mathrm{mM}$ EDTA instead of $\mathrm{CaCl}_{2}$. In order to measure the total collagenase activity, latent collagenase in the precipitate was activated with trypsin (Type III, Sigma Chemical Co., St. Louis, Mo.) for $3 \mathrm{~min}$ at $37^{\circ} \mathrm{C}$ followed by the addition of $625 \mu \mathrm{g} / \mathrm{ml}$ of soybean trypsin inhibitor (Worthington Biochemicals, Freehold, N. J.) in order to inactivate trypsin. Incubation was stopped by centrifuging the mixture at $30,000 \times g$ for $30 \mathrm{~min}$ at $4^{\circ} \mathrm{C}$, and the resulting supernatants were hydrolyzed in $5.8 \mathrm{~N} \mathrm{HCl}$ at $130^{\circ} \mathrm{C}$ for $3 \mathrm{hr}$. After equalizing all samples in the concentrations of $\mathrm{CaCl}_{2}$, EDTA, Tris and $\mathrm{NaCl}$, hydrolyzed products were lyophilized, resuspended in $0.4 \mathrm{~m} l$ of distilled water and assayed for hydroxyproline contents ${ }^{8}$. An aliquot of the precipitate at $6,000 \times g$ was directly subjected to hydrolysis and lyophilization in the same manner as above, and the total hydroxyproline content used for the incubation was measured. As the digestion of collagen by collagenase was proportional to time up to $18 \mathrm{hr}$ of the incubation, the activity of collagenase was expressed as $\mu \mathrm{g}$ of hydroxyproline solubilized for 1 hr of the incubation period.

For assay of collagenase activity in stigma and non-stigma regions, a microassay method of MoralEs et al. ${ }^{9)}$ was employed with slight modifications. In this assay, a total volume of $25 \mu l$ of the assay mixture was incubated in $50 \mu l$ graduated capillary tubes (Drummond Scientific Co., Broomall, Penn.), which had been sealed with Parafilm (American Can Co., Greenwich, Conn.) at both ends. After incubation, the content was quantitatively transferred to a centrifuge tube. The capillary tubes were rinsed three times with $50 \mu l$ each of distilled water and the washings were added to the samples. After centrifugation at 30,000 $\times g$ for $30 \mathrm{~min}$, the supernatant was assayed for hydroxyproline contents in the same manner as described above.

\section{Action of Collagenase on Synthetic Polypeptide}

Extraction of collagenase from the tissues was carried out by the method of WEEK et al. ${ }^{10}$ ) The synthetic octapeptide, dinitrophenyl-Pro-Gln-Gly-Ile-Ala-Gly-Gln-D-Arg-OH (DNP- 
peptide) was obtained from the Protein Research Foundation, Osaka, Japan, and was dissolved in the assay buffer containing $0.02 \%$ bovine serum albumin to achieve a final concentration of $5 \times 10^{-4} \mathrm{M}$. This solution $(0.1 \mathrm{ml})$ was mixed with $20 \mu l$ of $60 \mathrm{mM} \mathrm{CaCl} 2$ and $80 \mu l$ of the extracted collagenase and had been activated with $10 \mu \mathrm{g} / \mathrm{ml}$ trypsin. After incubation at $40^{\circ} \mathrm{C}$ for $16 \mathrm{hr}$, the reaction was stopped by adding $0.5 \mathrm{ml}$ of $1 \mathrm{~N} \mathrm{HCl}$. The fragments of DNP-peptide were removed from the incubation mixture with $1 \mathrm{~m} l$ of ethyl acetate: $n$-butanol $(100: 15, \mathrm{v} / \mathrm{v})$ by vigorous shaking followed by centrifugation at $1,000 \times g$ for $10 \mathrm{~min}$ at room temparature. The remaining aqueous layer was desalted on a Sephadex G10 column $(1 \times 19 \mathrm{~cm})$ and lyophilized. The $\mathrm{N}$-terminus of the peptide was determined by the dansyl method $^{11)}$.

\section{Results}

\section{Effect of Trypsin on Collagenase Activity}

In order to determine the optimum condition for the measurement of the total collagenase activity, the precipitate at $6,000 \times g$ obtained from the theca layer of the follicles which were 48 to $0.5 \mathrm{hr}$ before the expected ovulation, were incubated at $37^{\circ} \mathrm{C}$ for $3 \mathrm{~min}$ with various concentrations of trypsin. After the addition of trypsin inhibitor, the mixture was incubated at $40^{\circ} \mathrm{C}$ for $18 \mathrm{hr}$ in the presence of $\mathrm{CaCl}_{2}$ or EDTA. The amount of hydroxyproline solubilized during the control incubation in which EDTA was substituted for $\mathrm{CaCl}_{2}$, was subtracted from the values obtained in the incubation in the presence of $\mathrm{CaCl}_{2}$, and the resulting values were regarded as the amount of hydroxyproline solubilized by the collagenase. The results are shown in Fig. 1. The maximal activation of collagenase was obtained when the precipitate was incubated with $18 \mu \mathrm{g} / \mathrm{m} l$ of trypsin. Higher concentrations of trypsin than this caused a decrease in the activity.

\section{Intraclleular Distribution of Collagenase}

The precipitate at $6,000 \times g$ which was not treated with trypsin and trypsin inhibitor was resuspended in the supernatant at $6,000 \times g$ or in the assay buffer, and the effect of the su-

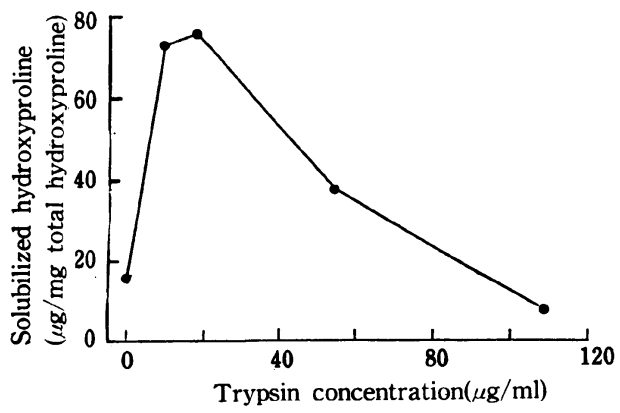

Fig. 1 Effect of Trypsin on Collagenase Activity.

The suspension of the precipitate at $6,000 \times \mathrm{g}$ of the homogenates of the follicle walls was preincubated with various concentrations of trypsin at $37^{\circ} \mathrm{C}$ for $3 \mathrm{~min}$ followed by the treatment of soybean trypsin inhibitor in order to inactivate trypsin. After the mixture was incubated for $18 \mathrm{hr}$ at $40^{\circ} \mathrm{C}$, soluble fraction was obtained by centrifugation at $30,000 \times g$ for $30 \mathrm{~min}$ at $4^{\circ} \mathrm{C}$ and subjected to quantitation of hydroxyproline contents as described in Materials and Methods. 
Table 1. Distribution of Collagenase Activity between Precipitate and Supernatant in the Homogenates of Theca Layer.

\begin{tabular}{llc}
\hline Treatment & Resuspension & Collagenase activity \\
\hline \multirow{2}{*}{ None } & Buffer & $4.5 \pm 2.2(5)$ \\
& Supernatant & $4.9 \pm 1.1(5)$ N.S. \\
\multirow{2}{*}{ Trypsin } & Buffer & $16.0 \pm 4.0(4)$ \\
& Supernatant & $15.5 \pm 6.0(4)$ N.S. \\
\hline
\end{tabular}

a) The homogenates of the theca layers were centrifuged at $6,000 \times g$ for $20 \mathrm{~min}$. The precipitate, resuspended in the assay buffer or the supernatant, was treated with $18 \mu \mathrm{g} / \mathrm{ml}$ trypsin at $40^{\circ} \mathrm{C}$ for 3 min followed by the addition of trypsin inhibitor, and collagenase activity was measured.

b) Each value expressed as $\mu \mathrm{g}$ of hydroxyproline solubilized for $1 \mathrm{hr}$ per $\mathrm{mg}$ of total hydroxyproline is mean $\pm \mathrm{S}$. D. of the number of independent experiments in parentheses. N. S. stands for the values not significantly different $(\mathrm{P}>0.05$ by paired $t$ test) from the corresponding controls.

pernatant on the collagenase activity was investigated. As shown in Table 1, the collagenase activity was not affected by the addition of the supernatant. The total collagenase activity in the precipitate which was treated with trypsin and trypsin inhibitor was also not affected by the addition of the supernatant. These results indicate that neither collagenase nor collagenase inhibitor exists in the supernatant. Therefore, only the precipitate at $6,000 \times g$ was employed for the further assay.

\section{Intercellular Distribution of Collagenase}

Cellular source of collagenase in the follicle was determined by comparing the collagenase activities in the precipitate of the intact follicle wall which consisted of the theca layer, the basal lamina and the granulosa layer, and in that of the isolated theca layer. As shown in Table 2, neither stimulatory nor inhibitory activities for collagenase existed in the granulosa layer or the basal lamina. In addition, these components did not contain significant amounts of collagen. Therefore, in the further studies, the theca layer was isolated from the follicles and used for the collagenase assay.

Table 2. The Source of Collagenase in the Follicle Wall

\begin{tabular}{llc}
\hline Treatment & Enzyme source & Collagenase $^{\mathrm{a}}$ activity $^{\mathrm{b})}$ \\
\hline \multirow{2}{*}{ None } & Theca layer & 3.9 \\
& Intact follicle wall & 3.6 \\
\multirow{2}{*}{ Trypsin } & Theca layer & 18.1 \\
& Intact follicle wall & 19.4
\end{tabular}

a) The homogenates of the isolated theca layers or the intact follicle wall were centrifuged at $6,000 \times g$ for $20 \mathrm{~min}$. The precipitate, resuspended in the assay buffer, were treated with trypsin at $40^{\circ} \mathrm{C}$ for $3 \mathrm{~min}$ followed by the addition of trypsin inhibitor, and collagenase activity was measured.

b) Each value expressed as $\mu \mathrm{g}$ of hydroxyproline solubilized for $1 \mathrm{hr}$ per mg of total hydroxyproline is mean of duplicated assays. 


\section{Collagenase Activity in Stigma and Non-stigma Regions During Ovulatory Process}

After the stigma and non-stigma regions were separated manually, collagenase activity was measured at various times during the ovulatory process. As shown in Table 3, collagenase activities were always higher in the stigma region than in the non-stigma region throughout the ovulatory process examined. There was no appreciable variation in activity in both regions until the time just before the predicted ovulation. In two experiments in which the follicles were obtained just after the rupture, the collagenase activity showed remarkably high in the stigma region, while the activity in non-stigma region remained low. Involvement of Collagenase in Collagen Degradation

In order to confirm whether the increased collagenase activity actually causes degradation of collagen in vivo, changes in the collagenase activity and the collagen content in the theca layer, which was assessed from the total hydroxyproline content, were studied during the ovulatory cycle. Since postovulatory follicles gradually decrease their sizes and become unpalpable within $72 \mathrm{hr}$ after ovulation, a decrease in the hydroxyproline content in the theca layer was expected probably accompaning with an increase in the collagenase activity. Fig. 2-A shows the changes in wet weight of the theca layer and its total hydroxyproline content during the ovulatory cycle. The wet weight of the theca layer increased as the follicle matured and started to decrease after ovulation. On the other hand, the total hydroxyproline content per follicle was highest at $3 \mathrm{hr}$ after ovulation, and then started to decrease. Fig.

Table 3. Collagenase Activity in Stigma and Non-stigma Region During Ovulatory Process.

\begin{tabular}{ccc}
\hline \multirow{2}{*}{$\begin{array}{c}\text { Time to ovuation } \\
\text { (hr) }\end{array}$} & \multicolumn{2}{c}{ Collagenase activity } \\
\cline { 2 - 3 }-24 & Stigma region & Non-stigma region \\
\hline & $7.0 \pm 0.4$ & $2.5 \pm 0.2$ \\
& $6.6 \pm 0.5$ & $2.5 \pm 0.2$ \\
-11 & $4.8 \pm 5.5$ & $3.2 \pm 0.4$ \\
-4 & $4.7 \pm 0.5$ & $1.9 \pm 1.1$ \\
-0 & $6.0 \pm 0.9$ & $1.5 \pm 0.2$ \\
(Just before ovulation) & $5.8 \pm 0.8$ & $1.0 \pm 0.5$ \\
& $5.9 \pm 1.1$ & $3.9 \pm 0.5$ \\
+0 & $9.4 \pm 0.9$ & $4.6 \pm 0.6$ \\
& & $6.1 \pm 0.3$ \\
(Just after ovulation) & $53.3 \pm 1.8$ & $1.1 \pm 0.1$ \\
& $61.1 \pm 16.5$ & $2.1 \pm 0.7$ \\
& $3.6 \pm 1.0$ & $1.9 \pm 0.4$
\end{tabular}

Follicles were obtained at various times in the ovulatory process. Collagenase activity was measured by the microassay after the stigma and nonstigma regions were separated manually. The values on the same row were from a single experiment in which 3 to 6 follicles were pooled. Values ex pressed as $\mu \mathrm{g}$ of hydroxyproline solubilized in $1 \mathrm{hr}$ per mg of total hydroxyproline are means $\pm \mathrm{S}$. D. of 4 assays from a single experiment. 
2-B shows the collagenase activity which was expressed as $\mu g$ of hydroxyproline solubilized for $1 \mathrm{hr}$ per theca layer obtained from a follicle. Changes in collagenase activity are well coincident with those of the hydroxyproline content in the theca layer especially after ovulation. It should be noted that the collagenase activity in the theca layer before ovulation was very low when the values were compared with those after ovulation which is during the degradation process of the postovulatory follicles. Total collagenase activity, which was measured after the activation of the latent collagenase by trypsin treatment, showed a remarkable

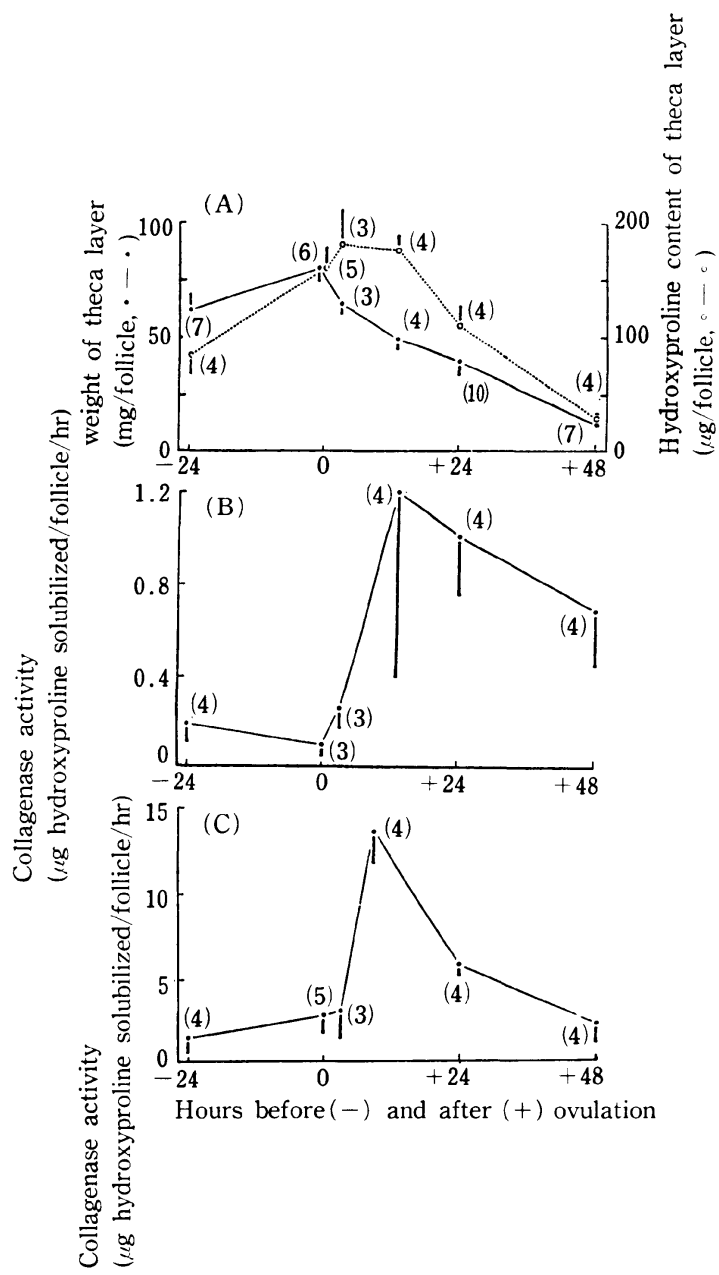

Fig. 2 Changes in Wet Weight, Total Hydroxyproline Content and Collagenase Activity in the Theca Layer Before and After Ovulation.

(A) Wet weight and total hydroxyproline contents of the follicles. (B) Collagenase activity and (C) total collagenase activity after the treatment with trypsin and trypsin inhibitor. Each value is expressed as $\mu \mathrm{g}$ of hydroxyproline solubilized for $1 \mathrm{hr}$ per follicle.

The points and bars represent means $\pm \mathrm{S}$. D. Where no line are shown, the S. D. lies inside the symbol. The figures in parantheses are the number of experiments at each point. 
increase from $3 \mathrm{hr}$ to $13 \mathrm{hr}$ after ovulation (Fig. 2-C), which indicates that the synthesis of collagenase had occurred in this period.

\section{Properties of Collagenase}

Since mammalian collagenases cleave the Gly-Ile bond of the synthetic peptide ${ }^{9.12}$, an experiment was performed to see whether the quail collagenase would cleave the same bond as mammalian collagenases do. After collagenase was extracted from the precipitate at 6,000 $\times g$ of the theca layer, an aliquot of the extracts was incubated with DNP-peptide to investigate the cleavage. Another aliquot was combined with the precipitate and subjected to the collagenase assay in order to see whether the addition of the extracted collagenase really enhance the activity.

When the extracted collagenase obtained from $5 \mathrm{mg}$ wet weight of the theca layer was added to the precipitates which was derived from $15 \mathrm{mg}$ wet weight of the tissue, collagenase activity increased $9.9 \%$ (0.91 vs $1.00 \mu \mathrm{g}$ hydroxyproline solubilized per $\mathrm{mg}$ of the total hydroxyproline per hr). When the extracted collagenase which was obtained from $3.3 \mathrm{mg}$ wet weight of the theca layer was treated with trypsin and trypsin inhibitor prior to the assay, collagenase activities were increased $70.3 \%$ (0.91 vs $1.55 \mu \mathrm{g}$ hydroxyproline solubilized per $\mathrm{mg}$ of the total hydroxyproline per hr). Finally, the extracted collagenase which had been activated with trypsin was incubated with DNP-peptide in the presence of $\mathrm{CaCl}_{2}$ or EDTA. When the mixture was incubated in the presence of EDTA, no appreciable cleavage of DNP-peptide was observed. The reaction product which was obtained from the incubation mixture in the presence of $\mathrm{CaCl}_{2}$ was examined for amino acids. The $\mathrm{N}$-terminal amino acid of the peptide which was left in the aqueous layer was Ile, which demonstrates that the extracted collagenase cleaved the DNP-peptide at the Gly-Ile bond.

\section{Discussion}

Many workers have been studying the changes in various proteolytic enzyme activities of the ovarian follicle in relation to ovulation in mammalian and avian species ${ }^{9,13-17)}$. All of the results showed that the enzyme activity decreased or remained constant throughout the period before ovulation, except one reported by Tojo et al. ${ }^{17}$, in which the non-specific neutral protease increased its activity just after ovulation in domestic fowl.

Although the stigma regions did not show any increase in the activity before ovulation in this study, the collagenase activity may be high at the time of ovulation from the follow ing reasons: First, it was reported that the stigma begin to become transparent, thin and ischemic in contrast with the hyperemia in the non-stigma region ${ }^{18}$. This macroscopic changes could be observed only a few minutes prior to the rupture of the follicle. Throughout these experiments, only one such typical follicle has been observed out of 24 follicles which were obtained from birds killed at the predicted time of ovulation. Therefore, if these morphological changes are induced by collagenase in the quail follicles, collagenase activity of the most follicles classified as those just before ovulation in the present study had not yet increased in the stigma region. It should be noted that the exact time of ovulation is difficult to predict from the time of oviposition of the previously ovulated follicle. Second, the hyperemia and increase in vascular permeability just before ovulation ${ }^{19)}$ may decrease the collagenase activity in the non-stigma region by bringing a great deal of various collagenase 
inhibitors in serum, such as $\beta_{1}$-anticollagenase ${ }^{20)}, \alpha_{1}$-antitrypsin ${ }^{21)}$, and $\alpha_{2}$-macroglobulin, which compose an irreversible complex with collagenase ${ }^{22)}$. This may be reason why the rupture never occurs in the non-stigma region. Indeed, an addition of $17 \%$ of quail serum to the incubation mixture of the collagenase assay reduced $66 \%$ of collagenase activity (Aoki and Mori, unpublished data). Because of the limited distribution of the blood vessels in the stigma region, the inhibition of collagenase activity by the inhibitors from serum may delay in comparison with that in the non-stigma region. The stigma regions of the follicles just after ovulation which did not show the increased collagenase activity might contain the one(s) which the inhibitors from serum had already spread over.

Collagenase are the only enzyme capable of cleaving the helical collagen molecule ${ }^{23,24)}$. At the start of collagen degradation, collagenase attacks initially upon the triple-helix of collagen at $3 / 4$ of the distance from the $\mathrm{N}$-terminus, releasing $3 / 4$ (TCA) and $1 / 4$ (TCB) fragments of the molecules which may be spontaneously denatured at the physiological condition. The denatured fragments could be degraded further to smaller peptides by a number of nonspecific proteases. Therefore, collagenase is regarded as a trigger of collagen degradation. In deed, changes in the collagenase activity was well coincident with those in the rate of collagen degradation in the theca layer after ovulation (Fig. 2).

Denatured collagen and synthetic peptides which are prepared to imitate the amino-acid sequences of the site attacked by collagenase have been widely used for studies of collagenase ${ }^{9.12)}$. However, these substances should not be employed for the substrate in collagenase assay, because the enzymes which cleave these collagen-like molucules but not the native collagen have been isolated ${ }^{25,26,27}$. Furthermore, vertebrate collagen is generally classified into six types, and some types of collagenase cannot cleave all of them ${ }^{28}$. Since the type of collagen in the quail follicle is unknown, the native collagen is the best substrate for the collagenase assay.

Latent collagenases which can be activated with trypsin have been found in several tissues and verified that they are enzyme-inhibitor complexes ${ }^{12,29,30}$. In the present study, the collagenase in the quail follicles was activated by trypsin. A large excess of trypsin rather decreased the activity which may be attributed to proteolytic destruction on collagenase itself by trypsin ${ }^{31)}$. WOESSNER ${ }^{32}$ ) suggested that enzyme-inhibitor complex is secreted by cells and deposited on the collagen fibers. When a second protease attacks the inhibitor, a large amounts of collagenase can be rapidly activated. This is a proposed mechanism for rapid breakdown of collagen during uterine involution after parturition. It should be emphasized that the proportion of the latent collagenase to the total collagenase in the quail follicles was much higher than that in the involuting rat uterus. In addition, the results of Table 1 showed no collagenase inhibitor in the supernatants at $6,000 \times g$ of quail follicles, whereas appreciable inhibitory activity was reported in those of rat uterus ${ }^{7}$. These data indicates to us that the affinity of collagenase to its inhibitor or the concentration of the inhibitor in quail follicles may be higher than that in rat uterus. Therefore, it is suggested that the quail follicles have the capacity of storing much larger amounts of collagenase in preparation for extremely rapid degradation of collagenous tissues at the rupture, which may be indicative of the mechanism of ovulation.

In the present study, it was shown that an increased collagenase activity could cause the 
degradation of collagen in vivo and the activity might be increased remarkably at the time of ovulation only in the stigma region from which rupture of follicles occurs. These results suggest that collagenase involves in the rupture of follicles.

\section{Summary}

Collagenase activity was determined at various stages before and after ovulation in the stigma and non-stigma region of quail follicle. There were no appreciable changes in the activity in both regions until the time just before ovulation. On the other hand, the stigma region showed a remarkable increase in the activity just after ovulation. In addition, changes in collagenase activity were well coincident with those in the rate of collagen degradation in the follicles after ovulation, which indicated that an increased collagenase activity may be able to cause the degradation of collagen in vivo. These results suggest that collagenase involves in the rupture of follicles.

\section{References}

1) EsPEy, L. L. (1967) Ultrastructure of the apex of the rabbit Graafian follicle during the ovulatory process: Endocrinology 81: 267-276.

2) Bjersing, L. and S. Cajander (1974) Ovulation and the mechanism of follicle rupture. V. Ultrastructure of tunica albuginea and theca externa of rabbit Craafian follicles prior to induced ovulation: Cell Tiss. Res. 153: 15-30.

3) Espey, L. L. and H. Lipner (1965) Enzyme-induced rupture of rabbit Graafian follicle: Am. J. Physiol. 208: 208-213.

4) Ichikawa, S., M. Оhта, H. Morioka and S. Murao (1983) Blockage of ovulation in the explanted hamster ovary by a collagenase inhibitor: J. Reprod. Fert. 68: 17-19.

5) Woodard, A.E. and F. B. Mather (1964) The timing of ovulation, movement of the ovum through the oviduct, pigmentation and shell deposition in Japanese quail (Coturnix coturnix japonica): Poult. Sci. 43: 1427-1432.

6) Gilbert, A. B., A. J. Evans, M. M. Perrry and M. H. Davidson (1977) A method for separating the granulosa cells, the basal lamina and the theca of the prevulatory ovarian follicle of the domestic fowl (Gallus domesticus): J. Reprod. Fert. 50: 179-181.

7) Ryan, J. N. and J.F. Woessner, Jr. (1971) Mammalian collagenase: Direct demonstration in homogenates of rat uterus: Biochem. Biophys. Res. Commun. 44: 144-149.

8) Woessner, J. F., Jr. (1961) The determination of hydroxyproline in tissue and protein samples containing small proportions of this imino acid: Arch. Biochem. Biophys. 93: 440-447.

9) Morales, T. I., J. F. Woessner, D. S. Howell, J. M. Marsh and W. L. LeMaire (1978) A micro assay for the direct demonstration of collagenolytic activity in Graafian follicles of the rat: Biochim. Biophys. Acta 524: 428-434.

10) Weeks, J. G., J. Halme and J. F. Woessner, Jr. (1976) Extraction of collagenase from the involuting rat uterus: Biochim. Biophys. Acta 445: 205-214.

11) Gray, W. R. (1972) End-group analysis using dansyl chloride: Methods Enzymol. 25: 121-138.

12) Kitamura, K., A. Ito and Y. Mori (1980) The existing forms of collagenase in the human uterine cervix: J. Biochem. 87: 753-760.

13) Espey, L. L. and P. Rondell (1968) Collagenolytic activity in the rabbit and sow Graafian follicle during ovulation: Am. J. Physiol. 214: 326-329.

14) Окаzaki, T., H. Okamura and T. Nishimura (1973) Collagenolytic activity in rat ovary during ovulation: Acta Obstet. Gynaec. Jap. 20: 112-117.

15) Nakamura, A. and S. Nakajo (1980) Proteolytic activity in the ovarian follicle wall of the Japanese quail (Coturnix coturnix japonica) during normal and LH-induced ovulation: Jpn. J. Fertil. Steril. 25: $98-102$.

16) Fujil, M., H. Tojo and K. Koga (1981) Determination and properties of collagenese in ovarian follicle wall of domestic fowl (Gallus domesticus). Int. J. Biochem. 13: 1043-1046.

17) Tojo, H., M. Fujnl and K. Ogawa (1982) Proteolytic enzymes and gonadal hormones of the ovarian 
follicle wall during ovulation in the domestic fowl (Gallus domesticus): J. Reprod. Fert. 64: 7377.

18) Yoshimura, Y. and S. Fujn (1979) Morphological changes of the stigma of follicle in the ovulatory process in the hen. Jpn. Poult. Sci. 16: 287-289.

19) Espey, L.L (1980) Ovulation as an inflammatory reaction-A hypothesis: Biol. Reprod. 22: 73-106.

20) Wooley, D. E., D. R. Roberts and J. M. Evanson (1976) Small molecular weight $\beta_{1}$ serum protein which specifically inhibits human collagenases: Nature 261: 325-327.

21) Eisen, A. Z., E. A. Bauer and J. J. Jeffrey (1971) Human skin collagenase, The role of serum alpha-globulins in the control of activity in vivo and in vitro: Proc. Natl. Acad. Sci. USA 68: 248251.

22) $\mathrm{ABE}, \mathrm{S}$, and $\mathrm{Y}$. NAGAI (1972) Interaction between tadpole collagenase and human $\alpha_{2}$-macroglobulin: Biochim. Biophs. Acta 278: 125-132.

23) Nordwig, A. (1971) Collagenolytic enzymes: Adv. Enzymol. 34: 155-205.

24) Harper, E. (1980) Collagenases: Ann. Rev. Biochem. 49: 1063-1078.

25) Harris, E. D., Jr. and S. M. Krane (1972) An endopeptidase from rheumatoid synovial tissue culture: Biochim. Biophys. Acta 258: 566-576.

26) Morales, T. I. and J. F. Woessner, Jr. (1977) Pz-peptidase from chick embryos. Purification, properties, and action on collagen peptides: J. Biol. Chem. 252: 4855-4860.

27) Kоваyashi, S. and Y. Nagai (1978) Human leucocyte neutral protease, with special reference to collagen metabolism: J. Biochem. 84: 559-567.

28) Liotta, L. A., S. Abe, P. G. Robey and G. R. Martin (1979) Preferential digestion of basement membrane collagen by an enzyme derived from a metastatic murine tumor: Proc. Natl. Acad. Sci. USA 76: 2268-2272.

29) Sellers, A., E. Cartwright, G. Murphy and J. J. Reynolds (1977) Evidence that latent collagenase are enzyme-inhibitor complexes: Biochem. J. 163: 303-307.

30) Sellers, A. and J. J. Reynolds (1977) Identification and partial characterization of an inhibitor of collagenase from rabbit bone: Biochem. J. 167: 353-360.

31) VAEs, G. (1972) The release of collagenase as an inactive proenzyme by bone explants in culture: Biochem. J. 126: 275-289.

32) Woessner, J.F., Jr. (1977) A latent form of collagenase in the involuting rat uterus and its activation by a serine protease: Biochem. J. 161: 535-542. 


\title{
ウズラ卵胞のコラゲナーゼ活性について
}

\author{
青木不学・森誠・河本馨・正田陽一
}

東京大学農学部 東京都文京区 113

近年, 哺乳動物において卵胞への蛋白分解酵素の局所 的投与によって排卵が誘起されること, コラゲナーゼの 抑制剂の投与によって排卵が阻止されること，さらに卵 胞スチグマ部の電子顕微鏡による観察で, 排卵後にコラ ーゲン線維が著しく崩壊していること等, 排卵に対する 蛋白分解酵素, 特にコラゲナーゼの関与を示唆する報告 があるが，その十分な証拠はまだ得られていない。そこ で本研究は, ウズラの排卵に批けるコラゲナーゼの関与 を明らかにする目的で, 排卵周期中の卵胞のコラゲナー ゼ活性を調べた。

コラゲナーゼの活性は, ゼラチンや合成ペプチドを基 質として测定する方法が広く用いられていたが、コラゲ ナーゼ以外にもこれらの基質を分解できる酵素の存在が 明らかとなってきた。したがって本研究では基質として ウズラ卵胞のコラーゲンを用いてコラゲナーゼの活性を 測定した。すなわち，卵胞膜ホモジネートを6, $000 \times g$ で20 分間遠心することによってコラゲナーゼをコラー ゲンとともに沈澱させ，これを $\mathrm{CaCl}_{2}$ を含む緩衝液に懸 濁し， $40^{\circ} \mathrm{C} て ゙ 18$ 時閒インキュベーションすることによ って闪溶化してくるヒドロキシブロリン㫣からコラゲナ
一ゼの活性を求めた。

その結果, ウズラの 卵胞膜に含まれるコラゲナーゼ は, トリプシンによって活性化されること, EDTA に よって活性が抑制されること，Gly-Ile 間を特異的に切 断すること等, 他の会椎動物のコラゲナーゼとよく一致 した特徵をそなえていた。次に卵胞膜をスチグマ部とそ れ以外の部分にわけて排卵周期中のコラゲナーゼの活性 の変化を調ベたところ, 排卵 24 時間前から排卵直前ま でいつでも他の部位と比較してスチグマ部に高い活性が 認められたが, 顕著な変動はみられなかった。排卵直後 の卵胞では，4 例中 2 例でスチグマ部に著しく高いコラ ダナーゼの活性が検出された。最後に、コラゲナーゼの 活性の上昇が実際に卵胞のコラーゲンの崩壊を引きおこ すことを確かめるため, 排卵後の卵胞膜のコラーゲン量 とコラゲナーゼの活性との関係を調べた。その結果, 排 卵後, コラゲナーゼの活性の高い時期にはコラーゲン量 の減少が激しいことがわかった。

以上の結果は, ウズラの排卵に卵胞膜のコラゲナーゼ が関与していることが示唆している。

（家禽会誌， 22，190～200, 1985） 